\title{
Dietary preferences of brachyuran crabs from Taiwan for marine or terrestrial food sources: evidence based on fatty acid trophic markers
}

Meike Stumpp ${ }^{1,2^{*}}$ (D), Reinhard Saborowski ${ }^{3}$, Simon Jungblut ${ }^{1,3,4}$, Hung-Chang Liu ${ }^{5}$ and Wilhelm Hagen ${ }^{1,6}$

\begin{abstract}
Background: Trophic interactions are key processes, which determine the ecological function and performance of organisms. Many decapod crustaceans feed on plant material as a source for essential nutrients, e.g. polyunsaturated fatty acids. Strictly herbivorous feeding appears only occasionally in marine decapods but is common in land crabs. To verify food preferences and to establish trophic markers, we studied the lipid and fatty acid composition of the midgut glands of two marine crab species (Grapsus albolineatus and Percnon affine), one semi-terrestrial species (Orisarma intermedium, formerly Sesarmops intermedius), and one terrestrial species (Geothelphusa albogilva) from Taiwan.

Results: All species showed a wide span of total lipid levels ranging from 4 to $42 \%$ of the dry mass (\%DM) in the marine $P$. affine and from 3 to $25 \% \mathrm{DM}$ in the terrestrial G. albogilva. Triacylglycerols (TAG) were the major storage lipid compound. The fatty acids 16:0, 18:1(n-9), and 20:4(n-6) prevailed in all species. Essential fatty acids such as 20:4(n-6) originated from the diet. Terrestrial species also showed relatively high amounts of $18: 2(n-6)$, which is a trophic marker for vascular plants. The fatty acid compositions of the four species allow to clearly distinguish between marine and terrestrial herbivorous feeding due to significantly different amounts of 16:0, 18:1(n-9), and 18:2(n-6).
\end{abstract}

Conclusions: Based on the fatty acid composition, marine/terrestrial herbivory indices were defined and compared with regard to their resolution and differentiating capacity. These indices can help to reveal trophic preferences of unexplored species, particularly in habitats of border regions like mangrove intertidal flats and estuaries.

Keywords: Decapoda, Lipids, Triacylglycerols, Fatty acids, Midgut gland, Trophic relationships, Algae, Vascular plants

\footnotetext{
* Correspondence: mstumpp@zoologie.uni-kiel.de

'University of Bremen, BreMarE (Bremen Marine Ecology), Marine Zoology, PO Box 330 440, 28334 Bremen, Germany

${ }^{2}$ Christian-Albrechts-University, Zoological Institute, Am Botanischen Garten 3-9, 24118 Kiel, Germany

Full list of author information is available at the end of the article
}

(c) The Author(s). 2021 Open Access This article is licensed under a Creative Commons Attribution 4.0 International License, which permits use, sharing, adaptation, distribution and reproduction in any medium or format, as long as you give appropriate credit to the original author(s) and the source, provide a link to the Creative Commons licence, and indicate if changes were made. The images or other third party material in this article are included in the article's Creative Commons licence, unless indicated otherwise in a credit line to the material. If material is not included in the article's Creative Commons licence and your intended use is not permitted by statutory regulation or exceeds the permitted use, you will need to obtain permission directly from the copyright holder. To view a copy of this licence, visit http://creativecommons.org/licenses/by/4.0/ The Creative Commons Public Domain Dedication waiver (http://creativecommons.org/publicdomain/zero/1.0/) applies to the data made available in this article, unless otherwise stated in a credit line to the data. 


\section{Background}

Many decapod crustaceans feed on plant material as a supplementary source of vitamins or essential fatty acids. Exclusively herbivorous feeding, however, is rare in marine species [1], but common in terrestrial species, i.e. land crabs [2, 3]. Some land crabs feed on seeds and seedlings, but most species consume leaf litter, thus, accelerating its decomposition and the turnover of nutrients [2]. In subtropical habitats, up to $79 \%$ of plant litter is decomposed by terrestrial crustaceans [4]. Moreover, crabs retain leaves in their burrows, considerably increasing nutrient concentrations in the soil, hence, fulfilling important ecological and biogeochemical functions.

Plant diet is usually of low nutritional quality, i.e. low in nitrogen and lipid levels. Primarily herbivorous crustaceans compensate this by increased feeding rates or by supplementing their diet with fruits or remains of animals [3, 5-7]. A premise for evaluating the impact of species on food webs and nutrient cycling is the knowledge of their feeding preferences and origin of their food. Especially in subtropical habitats and land-sea transition zones, where land crabs are common, it is often unknown, whether a crab species relies mostly on marine or terrestrial food sources. Fatty acid trophic markers can help to identify preferred food sources. The fatty acid trophic marker (FATM) concept is based on the observation that fatty acids (FAs) characteristic of the diet can be detected in higher quantities in the consumer's lipids [8]. Excess energy gained from the food is stored in body reserves. While the size and lipid content of the midgut gland is an indicator of the crab's overall condition [9-11], the FA composition of the stored lipids can be used for the identification of food sources. An advantage of this FATM approach is the avoidance of biases, which occur when analyzing, e.g., gut contents. Such analyses tend to overestimate recently ingested food items and to underestimate food items, which are fragile and easy to digest. Hence, gut contents only provide a snapshot impression, whereas FA compositions integrate the feeding preferences of the respective animals over much longer time scales, usually weeks $[8,12$,

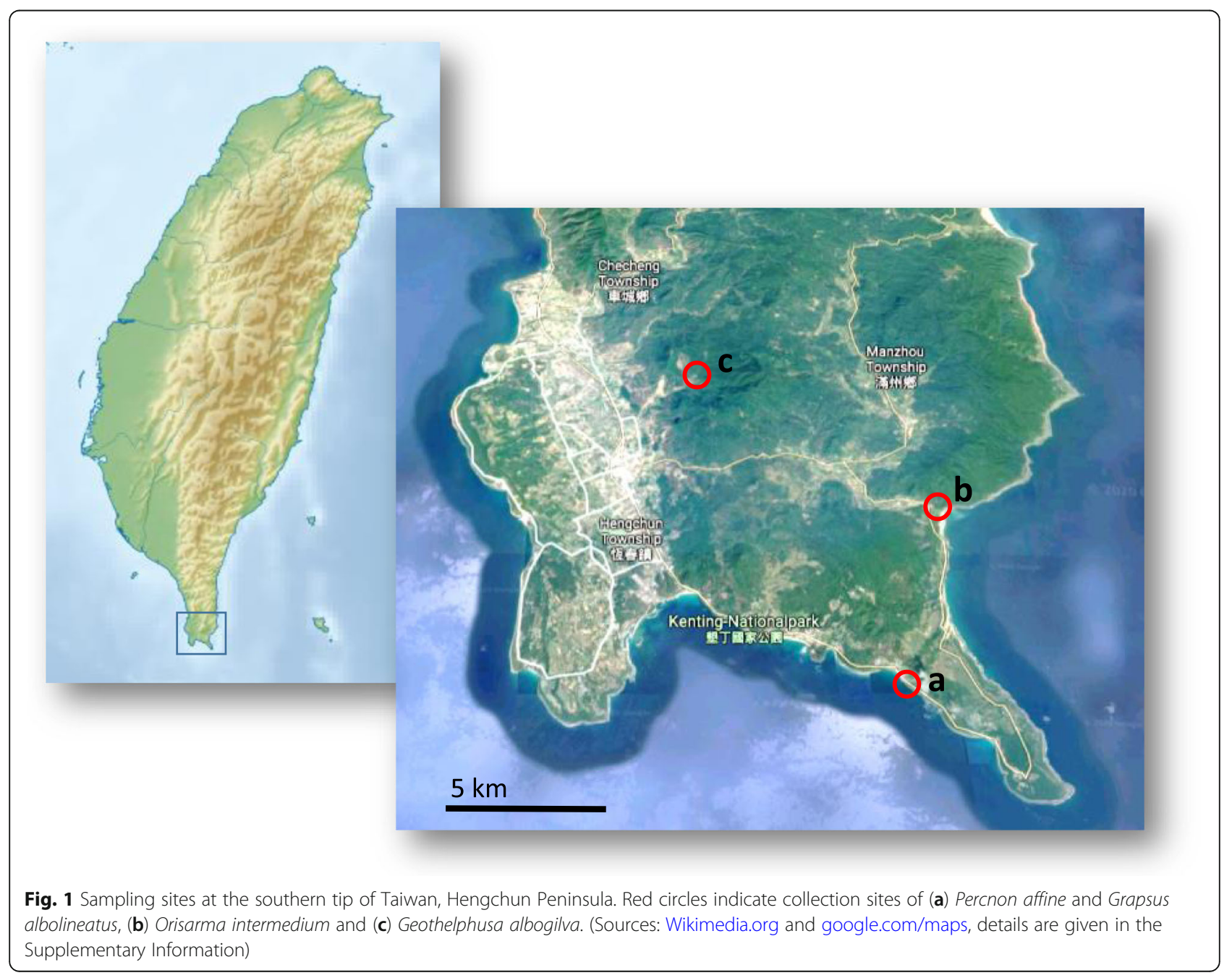


13]. The FATM concept is well established for pelagic organisms $[8,14]$, and it has also been applied to benthic organisms [15]. Recently, this concept has been successfully used to compare the feeding preferences of two cooccurring temperate crabs and novel FA-based dietary indices have been established [16]. These indices were developed to specifically detect differences in the consumption of green, brown, and red macroalgae as well as diatoms and animal-based food. In this case, the detected differences in the dietary preference of the invasive Asian shore crab Hemigrapsus sanguineus and the native European shore crab Carcinus maenas suggested that both species do not compete for food, though living in the same habitat.

To distinguish between marine and terrestrial feeding preferences, we studied the energy storage capacities and FA compositions of four crab species from different habitats in Taiwan (Fig. 1, Table 1): Percon affine is a marine species that lives in the lower intertidal of rocky shores down to $10 \mathrm{~m}$ depth and it mainly feeds on macroalgae (Hung-Chang Liu, pers. obs.). Grapsus albolineatus is a marine species, which can be found above the high tide mark of rocky shores. It feeds primarily on filamentous green algae like Ulva spp., but it opportunistically includes carrion in its diet $[6,17]$. The semi-terrestrial Orisarma intermedium (formerly Sesarmops intermedius) occurs along coastal rivers, estuaries, and in salt marshes $[18,19]$. It feeds on grass and fresh or old leaf litter [19] (Hung-Chang Liu, pers. obs.). The fully terrestrial Geothelphusa albogilva is endemic to Taiwan and occurs along mountain rivers distant from the coast [20]. This species mainly feeds on leaf litter (HungChang Liu, pers. obs.).

The aim of this study is to develop and test dietary indices according to the FATM concept to determine feeding preferences of the four crab species, and to assess, whether alimentary plant material originated from marine or terrestrial sources. For the development of meaningful indices, we also tested the effect that a low lipid content has on the newly developed indices in the four species.

\section{Results}

A comprehensive data set of this study is presented in the Supplementary Information (S).

\section{Somatic parameters}

The marine crabs, Percnon affine and Grapsus albolineatus, and the terrestrial crab, Geothelphusa albogilva, analyzed in this study were of similar size. Their fresh masses were $25.4 \pm 10.6 \mathrm{~g}, 23.1 \pm 9.6 \mathrm{~g}$, and $22.5 \pm 5.9 \mathrm{~g}$, respectively (Fig. 2a, Table S1). The semi-terrestrial Orisarma intermedium was significantly smaller and lighter $(13.1 \pm 3.2 \mathrm{~g})$ than the other species (one Way ANOVA, $\left.\mathrm{F}_{(3.44)}=5.587, p=0.0025\right)$.

The hepatosomatic indices (HSI, Fig. 2b, Table S2) were highest in the terrestrial species with $4.5 \pm 1.3$ in $O$. intermedium and $4.7 \pm 1.3$ in G. albogilva. The HSI of the marine $P$. affine was slightly lower $(3.9 \pm 0.8)$. G. albolineatus had the lowest HSI $(3.0 \pm 0.8)$. The HSI differed significantly between species (one Way ANOVA, $\left.\mathrm{F}_{(3.44)}=6.822, p=0.0007\right)$.

\section{Total lipid content}

The total lipid contents (TL in $\%_{\mathrm{DM}}$ ) of the midgut glands were displayed on an ordinal scale, ranked from minimum to maximum values (Fig. 3). Lipid levels in the marine species ranged from 4 to $42 \%_{\mathrm{DM}}$ (average $22.3 \%$ ) in P. affine and from 12 to $39 \%_{\mathrm{DM}}$ (average $21.7 \%$ ) in G. albolineatus. Data of starved animals, displayed as open symbols, were distributed along the whole scale (Fig. 3a). Applying the sigmoidal model, maximum lipid values were projected to reach about $50 \%_{\mathrm{DM}}$ in either marine species. The lipid content of the semi-terrestrial $O$. intermedium ranged from 5 to $35 \%_{\mathrm{DM}}$ (average 16.3\%) and that of the terrestrial G. albogilva from 3 to $25 \%_{\mathrm{DM}}$ (average 9.0\%) (Fig. 3b). Similar to the other specimens, data of starved animals were distributed along the ascending series. No approximation towards a maximum lipid level could be deduced from the curve.

\section{Lipid classes}

Triacylglycerols (TAG) were the only major storage lipid in all investigated species. The amount of TAG correlated with the total lipid content (Fig. 4).

Maximum values ranged from $70 \% \mathrm{TL}$ in Grapsus albolineatus (Fig. 4a) to $91 \%_{\mathrm{TL}}$ in Geothelphusa albogilva (Fig. 4b). Wax ester and sterol ester (WE/SE) levels were low in all species $\left(<6.9 \%_{\mathrm{TL}}\right)$ except in Grapsus albolineatus, where WE/SE reached a maximum of $16.6 \%_{\mathrm{TL}}$. The amount of wax esters showed no statistically significant

Table 1 Species names, life styles, and sampling sites of the four crab species (Decapoda, Brachyura) collected in southern Taiwan in May 2007

\begin{tabular}{llllll}
\hline Species & Family & Life style & \multicolumn{1}{c}{ Habitat } & Feeding mode & Sampling position \\
\hline Percnon affine & Percnidae & marine & lower rocky intertidal & herbivorous & $21^{\circ} 55^{\prime} 54.6^{\prime \prime} \mathrm{N}, 120^{\circ} 49^{\prime} 29.0^{\prime \prime} \mathrm{E}$ \\
Grapsus albolineatus & Grapsidae & marine & spray zone, rock pools & herbi-/omnivorous & $21^{\circ} 55^{\prime} 54.6^{\prime \prime} \mathrm{N}, 120^{\circ} 49^{\prime} 29.0^{\prime \prime} \mathrm{E}$ \\
Orisarma intermedium & Sesarmidae & semi-terrestrial & estuaries, salt marshes & herbivorous & $21^{\circ} 59^{\prime} 17.1^{\prime \prime} \mathrm{N}, 120^{\circ} 50^{\prime} 40.2^{\prime \prime} \mathrm{E}$ \\
Geothelphusa albogilva & Potamidae & terrestrial & mountain rivers & herbivorous & $22^{\circ} 02^{\prime} 30.8^{\prime \prime} \mathrm{N}, 120^{\circ} 46^{\prime} 13.3^{\prime \prime} \mathrm{E}$ \\
\hline
\end{tabular}


a)

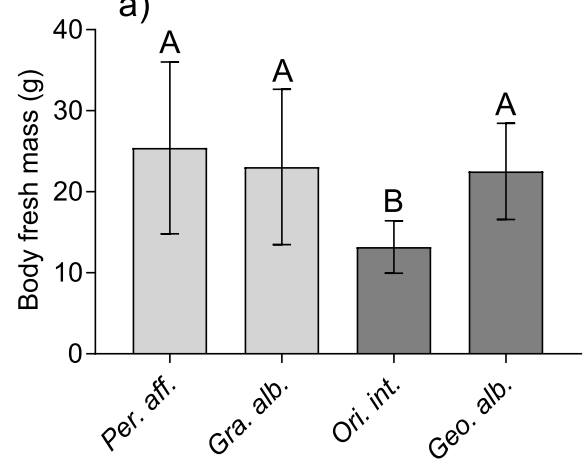

b)

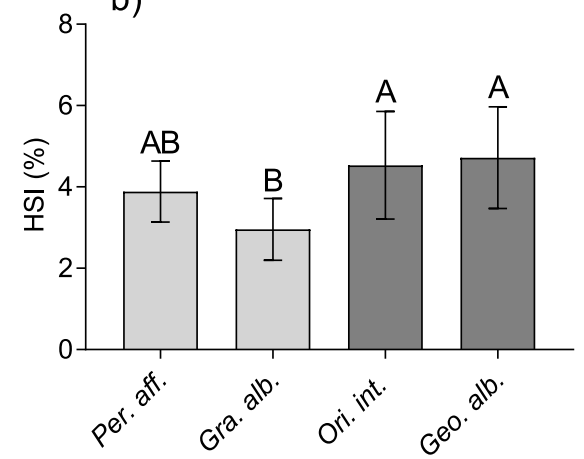

Fig. 2 Body fresh mass (a) and hepatosomatic index (HSI) (b) of the four crab species (light grey: marine species, dark grey: terrestrial species). Means $\pm \mathrm{SD}, n=12$. Different letters indicate significant statistical difference (ANOVA, $p<0.05$ )

correlation with the total lipid content. The amounts of free fatty acids (FFA) and sterols (ST) were negligible (Table 2). The shares of polar lipids (PL) were negatively correlated with TAG values.

\section{Fatty acids and fatty alcohols}

The FA compositions of the midgut glands of the four crab species differed from each other (Table 3). Major FA representing more than $10 \%_{\text {TFA }}\left(\%_{\text {total fatty acid }}\right)$, were palmitic acid (16:0), arachidonic acid (20:4(n-6)), oleic acid (18:1(n-9)), and linoleic acid (18:2(n-6)). While 16:0 was the dominant FA in $P$. affine with $27.2 \%_{\mathrm{TFA}}$, it was lower in G. albolineatus $\left(19.0 \%_{\mathrm{TFA}}\right)$ and O. intermedium $\left(13.7 \%_{\mathrm{TFA}}\right)$. A minimum of $10.8 \%_{\text {TFA }}$ was present in G. albogilva. Percentages of 20:4(n-6) comprised a wide range among marine and terrestrial species: $13.3 \%_{\mathrm{TFA}}$ and $18.2 \%_{\mathrm{TFA}}$ for $P$. affine and G. albolineatus, respectively, and $13.5 \%_{\mathrm{TFA}}$ and $18.9 \%_{\mathrm{TFA}}$ for O. intermedium and G. albogilva, respectively. 18:1(n-9) was high in the semi-terrestrial O. intermedium ( $\left.16.5 \%_{\text {TFA }}\right)$ and the terrestrial G. albogilva $\left(19.1 \%_{\text {TFA }}\right)$. In contrast, the $18: 1(n-9)$ values of the two marine species were much lower, accounting for $6.9 \%_{\mathrm{TFA}}$ in $P$. affine and $9.9 \%_{\mathrm{TFA}}$ in
G. albolineatus. The same was true for 18:2(n-6): the marine species $P$. affine and G. albolineatus had low levels with 4.1 and $5.9 \%_{\text {TFA }}$, respectively, whereas $O$. intermedium and G. albogilva showed higher values of 10.1 and $11.2 \%{ }_{\mathrm{TFA}}$, respectively.

Among the other FA, palmitoleic acid (16:1(n-7)) was highest in $P$. affine with $4.3 \%_{\mathrm{TFA}}$, while the other species showed lower values between 1.5 and $2.6 \%_{\mathrm{TFA}}$. The opposite was detected for stearic acid (18:0): P. affine had lowest levels with $7.3 \%_{\mathrm{TFA}}$ and the other species ranged between 7.8 and $9.6 \%_{\text {TFA }}$. 20:5(n-3) was relatively high in P. affine with $9.8 \%$ TFA, but only comprised between $5.3 \%_{\text {TFA }}$ and $7.8 \%_{\text {TFA }}$ in the other species.

The potential food sources, algae, grasses, and leaf litter, contained high amounts of palmitic acid (16:0) (19.4 to $27.2 \%_{\text {TFA }}$, Table 3). Leaf litter was also rich in stearic acid (18:0) $\left(13.5 \%_{\text {TFA }}\right)$. All samples contained high amounts of linoleic acid (18:2(n-6)) and $\alpha$-linolenic acid (18:3(n-3)), the latter showing a maximum of $47.2 \%_{\mathrm{TFA}}$ in the grasses.

All species had very low amounts of fatty alcohols, usually 14:0 and/or 16:0. Maximum values of $0.4 \%_{\mathrm{TL}}$ were present in G. albogilva. Apparently, fatty alcohols
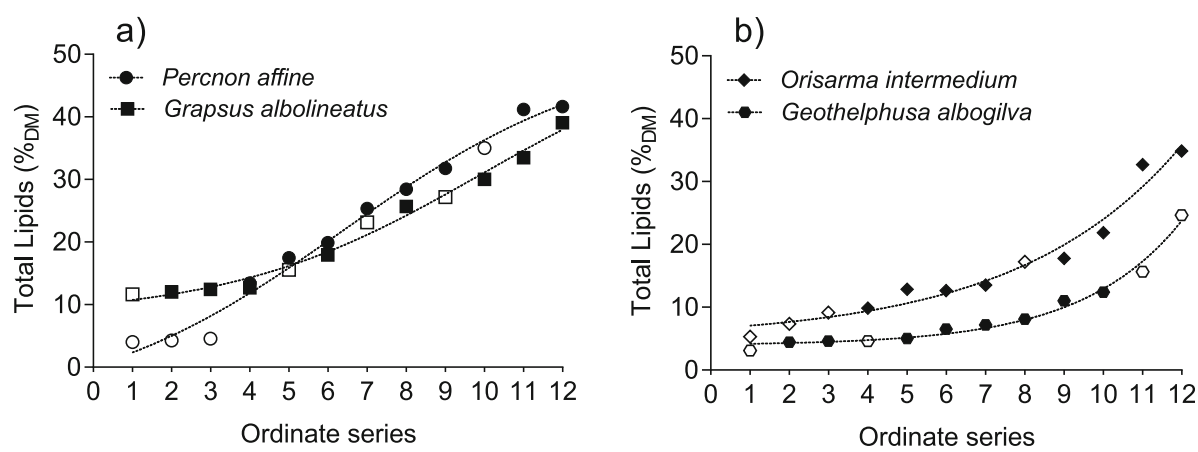

Fig. 3 Ordinate series of increasing total lipids in the midgut glands of (a) marine species and (b) semi-terrestrial and terrestrial species. Filled symbols show samples, which were immediately processed after sampling ( $n=8$ for each species) and open symbols indicate samples after 12 days of starvation ( $n=4$ for each species). The lines are based on a sigmoidal regression model 

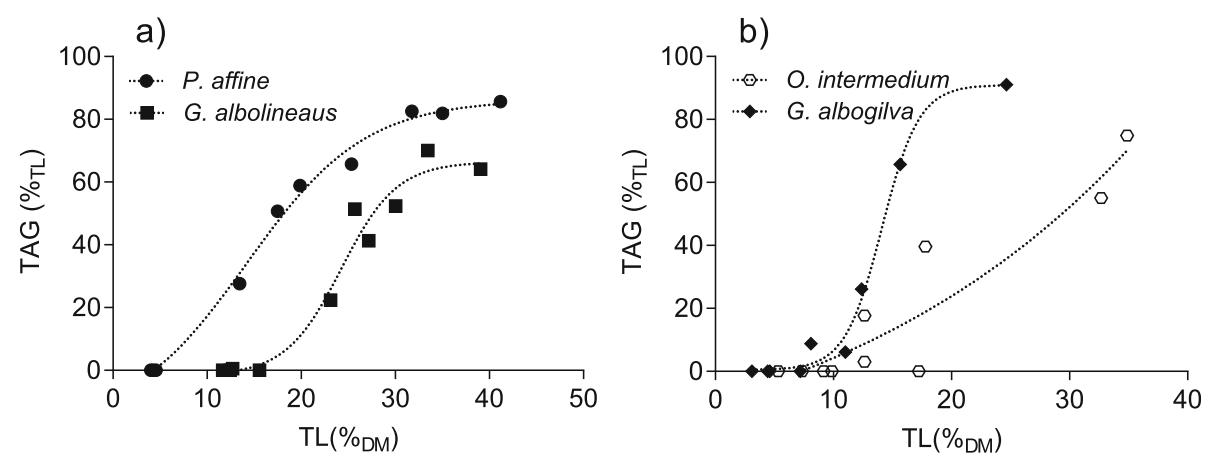

Fig. 4 Relationship between total lipids (\% $\left.\%_{D M}\right)$ and the share of triacylglycerols (TAG) in the midgut glands of (a) marine species and (b) terrestrial species. The dotted lines show the best fit of the sigmoidal regression model ( $n=12$ for each species)

were minor components in these species and, hence, not considered in further analyses.

The Principal Component Analysis (PCA) of the FA compositions of the four crab species (midgut glands) and the three dietary items revealed a distinct separation of species with increasing lipid content. The first three PCs explained $81.3 \%$ of the variation. PC1 covered $45.9 \%$ of variation (Fig. 5a, b) and was primarily determined according to their Eigen vectors by the FA 20:4(n-6), 16:0, 18:3(n-3), 14:0, and 18:0 (Tables S3, S4). The individuals of each species lined up according to their lipid content, which was graphically indicated by the intensity of the symbol colors (Fig. 5a). In all crustacean species, the amount of storage lipids correlated positively with the amount of the saturated FA 16:0 and negatively with the FAs 20:4(n-6) and 18:0 (Fig. S1, Table S1). PC2 (23.3\%) separated the four crustacean species and particularly the marine species from the semi-terrestrial and terrestrial species. PC2 was primarily determined by $18: 2(\mathrm{n}-6)$, 18:1(n-9), and 18:3(n-3). The separation along PC2 was most distinct in the lipid-rich individuals. Lipid-poor individuals of all species showed a more similar lipid composition and approached each other along PC1 and PC2 (Fig. 5a). PC3 covered another $12.1 \%$ of the variation and was primarily determined by 18:1(n-9), 18:3(n-3), and $16: 2(n-4)$. It principally separated the crustaceans from the dietary plant material.

Table 2 Lipid class composition (\% of total lipid) of the four crab species. Means \pm standard deviation, $n=10$ for each species (for technical reasons, only 10 of the 12 samples were analyzed)

\begin{tabular}{lllll}
\hline Lipid class $\left(\right.$ \% $\left._{\mathrm{TL}}\right)$ & Per. aff. & Gra. alb. & Ori. int. & Geo. alb. \\
\hline Wax or sterol esters & $1.3 \pm 0.9$ & $9.2 \pm 4.2$ & $1.5 \pm 1.5$ & $2.5 \pm 2.6$ \\
Triacylglycerols & $44.8 \pm 35.7$ & $30.6 \pm 28.8$ & $19.4 \pm 28.0$ & $19.9 \pm 32.1$ \\
Free fatty acids & $0.2 \pm 0.2$ & $1.2 \pm 1.0$ & $0.6 \pm 0.6$ & $0.1 \pm 0.3$ \\
Sterols & $3.4 \pm 3.4$ & $4.5 \pm 2.6$ & $3.2 \pm 2.5$ & $6.0 \pm 3.0$ \\
Polar lipids & $50.3 \pm 32.5$ & $54.5 \pm 27.7$ & $75.2 \pm 27.0$ & $71.6 \pm 29.2$ \\
\hline
\end{tabular}

\section{Dietary indices}

Dietary indices varied considerably among the four crab species. The index for the consumption of vascular plants $\mathrm{I}_{V}$ was lowest in the two marine species $P$. affine $(4.1 \pm 0.9)$ and $G$. albolineatus, $(5.9 \pm 1.4)$ but significantly higher in the two terrestrial species $O$. intermedium $(10.1 \pm 2.8)$ and $G$. albogilva (11.2 \pm 3.7$)$ (Fig. 6a, Table S5).

The $16: 0 / \mathrm{I}_{\mathrm{V}}$ index for marine/terrestrial diet decreased significantly from the marine to the terrestrial species (Fig. 6b, Table S5). P. affine showed the highest mean value $(6.7 \pm 3.1)$, followed by $G$. albolineatus $(3.5 \pm 2.0)$, O. intermedium $(1.4 \pm 0.6)$, and G. albogilva $(1.0 \pm 0.3)$. The $16: 0 / \mathrm{I}_{V}$ indices of $O$. intermedium and G. albogilva were not significantly different from each other.

The second marine/terrestrial diet index, the $\Sigma_{\text {algae } F A} / I_{V}$ index, showed a similar pattern as the 16:0/I ${ }_{V}$ index (Fig. 6c, Table S5). The two marine species, $P$. affine and G. albolineatus, had mean values of $8.4 \pm 1.5$ and $6.1 \pm 1.2$, respectively. They were significantly different from those of the two terrestrial species, O. intermedium $(3.3 \pm 1.8)$ and G. albogilva (3.0 \pm 1.6$)$.

Additional dietary indices of the four crab species are listed in Table 4. The carnivory index $\mathrm{I}_{C a}$ of the two terrestrial species, O. intermedium and G. albogilva, was higher than that of the two marine species, $P$. affine and G. albolineatus. The Chlorophyta index $\mathrm{I}_{C h}$ was lowest in the terrestrial G. albogilva. The index for Phaeophyceae consumption $\mathrm{I}_{P}$ decreased from the marine towards the terrestrial species, whereas the index for Rhodophyta $\mathrm{I}_{R}$ was quite similar among the four species. The Bacillariophyceae index $\mathrm{I}_{B}$ was relatively high in $P$. affine, intermediate in O. intermedium and G. albolineatus, and low in G. albogilva.

\section{Discussion}

Information about the feeding preferences and food sources of the brachyuran crabs from Taiwan is sparse and mostly based on anecdotic reports, field 
Table 3 Fatty acid concentrations (percent of total fatty acids, \% TFA) of the four crab species (mean \pm SD, $n=12$ for each species). Bold numbers emphasize FA contents $>10 \%_{\text {TFA. }}{ }^{-}$" = traces $<0.1 \%_{\text {TFA }}$ or not detected. * The term "Grasses" comprises species of the genus Panicum and Paspalum

\begin{tabular}{|c|c|c|c|c|c|c|c|}
\hline Fatty acid (\% $\left.\%_{\text {TFA }}\right)$ & Per. aff. & Gra. alb. & Ori. int. & Geo. alb. & Ulva spec. & Grasses* & Leaf litter \\
\hline $14: 0$ & $1.6 \pm 1.1$ & $0.6 \pm 0.7$ & $0.5 \pm 0.6$ & $0.1 \pm 0.2$ & 2.1 & 0.6 & 2.4 \\
\hline $16: 0$ & $27.2 \pm 9.9$ & $19.0 \pm 8.6$ & $13.7 \pm 6.5$ & $10.8 \pm 3.9$ & 27.2 & 19.4 & 26.0 \\
\hline $16: 1(n-7)$ & $4.3 \pm 2.1$ & $2.6 \pm 0.9$ & $2.3 \pm 1.6$ & $1.5 \pm 1.4$ & 4.0 & - & 1.5 \\
\hline $16: 1(n-5)$ & $0.8 \pm 0.3$ & $0.4 \pm 0.9$ & $1.3 \pm 0.4$ & $0.9 \pm 0.3$ & - & - & - \\
\hline $16: 2(n-4)$ & $2.0 \pm 1.3$ & $1.6 \pm 1.0$ & $1.0 \pm 1.6$ & $4.2 \pm 1.8$ & 0.3 & - & 0.5 \\
\hline $16: 4(n-1)$ & $0.1 \pm 0.1$ & - & $0.8 \pm 0.7$ & - & - & - & - \\
\hline $17: 0$ & $1.6 \pm 0.4$ & $1.9 \pm 0.5$ & $1.7 \pm 0.3$ & $1.4 \pm 0.2$ & 1.4 & $0.7-$ & 1.1 \\
\hline $18: 0$ & $7.3 \pm 4.6$ & $9.6 \pm 2.5$ & $8.8 \pm 1.9$ & $7.8 \pm 1.2$ & 0.8 & 3.2 & 13.5 \\
\hline $18: 1(n-9)$ & $6.9 \pm 1.5$ & $9.9 \pm 1.0$ & $16.5 \pm 5.1$ & $19.1 \pm 4.3$ & 5.3 & 3.6 & 8.5 \\
\hline $18: 1(n-7)$ & $3.6 \pm 0.7$ & $5.7 \pm 1.5$ & $2.0 \pm 0.6$ & $1.2 \pm 0.4$ & 5.8 & 0.5 & 1.1 \\
\hline $18: 2(n-6)$ & $4.1 \pm 0.9$ & $5.9 \pm 1.3$ & $10.1 \pm 2.8$ & $11.2 \pm 3.7$ & 14.5 & 15.9 & 12.2 \\
\hline $18: 3(n-3)$ & $2.4 \pm 0.9$ & $1.9 \pm 0.6$ & $2.6 \pm 1.3$ & $2.0 \pm 1.0$ & 16.1 & 47.2 & 13.8 \\
\hline $18: 4(n-3)$ & $1.5 \pm 1.0$ & $0.4 \pm 0.6$ & $0.3 \pm 1.0$ & - & 3.8 & - & - \\
\hline $20: 0$ & $0.7 \pm 0.3$ & $0.9 \pm 0.2$ & $0.8 \pm 0.2$ & $1.0 \pm 0.2$ & - & 1.6 & 3.5 \\
\hline $20: 2(n-6)$ & $1.0 \pm 0.4$ & $1.1 \pm 0.4$ & $0.9 \pm 0.8$ & $1.1 \pm 0.5$ & - & 0.3 & - \\
\hline $20: 3(n-6)$ & $1.2 \pm 0.2$ & $1.1 \pm 0.2$ & $0.7 \pm 0.2$ & $0.9 \pm 0.2$ & 0.7 & - & 0.7 \\
\hline $20: 4(n-6)$ & $13.3 \pm 5.5$ & $18.2 \pm 6.5$ & $13.5 \pm 7.6$ & $18.9 \pm 9.3$ & 2.6 & - & 0.5 \\
\hline $20: 5(n-3)$ & $9.8 \pm 1.6$ & $5.8 \pm 1.8$ & $7.8 \pm 3.9$ & $5.3 \pm 2.7$ & 2.8 & 1.3 & 4.2 \\
\hline $22: 0$ & $0.5 \pm 0.1$ & $0.9 \pm 0.4$ & $0.8 \pm 0.2$ & $1.2 \pm 0.2$ & 0.4 & - & - \\
\hline $22: 5(n-3)$ & $0.9 \pm 0.3$ & $1.2 \pm 0.9$ & $0.8 \pm 0.2$ & $0.6 \pm 0.3$ & 1.5 & 2.4 & 3.9 \\
\hline $22: 6(n-3)$ & $1.6 \pm 0.9$ & $1.3 \pm 0.9$ & $2.4 \pm 0.9$ & $0.9 \pm 0.5$ & 0.3 & - & - \\
\hline
\end{tabular}

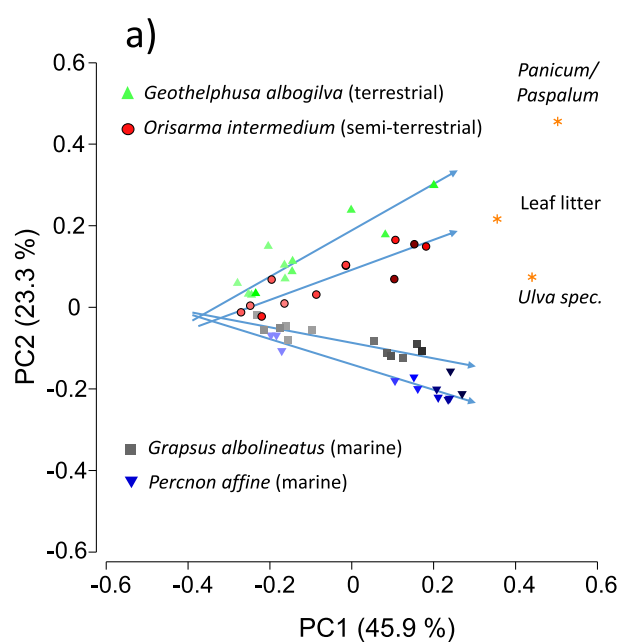

b)

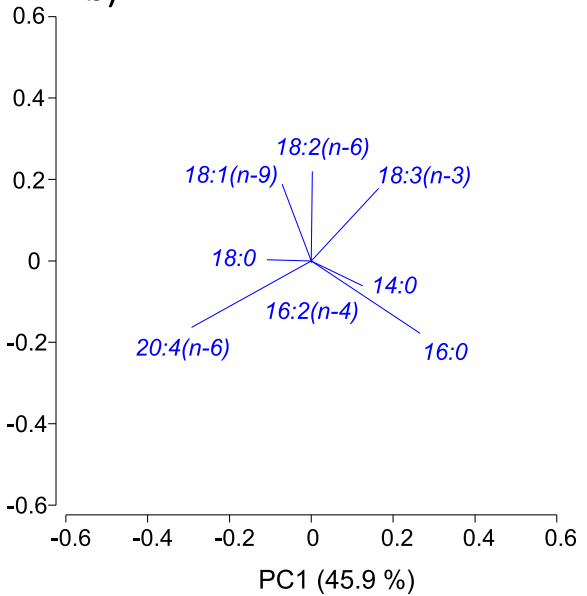

Fig. 5 Principal Component Analysis (PCA) of the fatty acid compositions of the four crab species (midgut glands) and three dietary items from Taiwan. Data points (a), major vectors (b). Increasing lipid content is indicated by increasing intensity of the symbol colors. See also animated gif in the Supplementary Information 


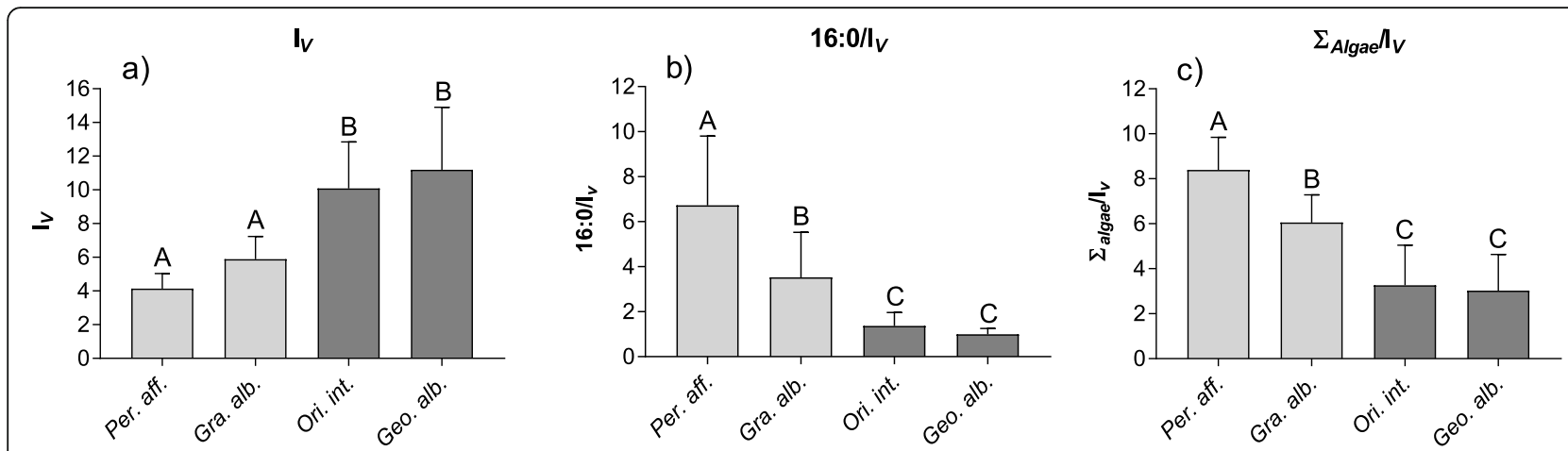

Fig. 6 Selected dietary indices are presented: $I_{V}(\mathbf{a}), 16: 0 / I_{V}(\mathbf{b})$, and $\Sigma_{\text {algae }} \mathrm{FA}_{\mathrm{A}} / I_{\bigvee}(\mathbf{c})$ calculated from the fatty acid compositions of the midgut glands of four crab species from Taiwan. Light grey: marine species; dark grey: terrestrial species. Means $\pm S D, n=12$ each. Bars sharing the same letter are not significantly different from each other (One-Way ANOVA, $p<0.05$ )

observations, feeding experiments, or gut content analyses [17, 21], (Hung-Chang Liu, pers. comm.). Here, we provide lipid and fatty acid profiles, which allow identifying major dietary preferences according to the fatty acid trophic marker concept.

\section{Energy storage}

The hepatosomatic index (HSI) and total lipid levels (TL in \% $\%_{\mathrm{DM}}$ ) of midgut glands are commonly used to characterize the nutritional condition and energy storage capacities of decapod crustaceans. Both HSI and TL of the four crab species ranged within previously reported levels of other (sub-) tropical crabs [22, 23]. The two marine species, Percnon affine and Grapsus albolineatus, as well as Orisarma intermedium showed similar average lipid levels of their midgut glands. Only Geothelphusa albogilva had lower TL values, possibly due to its reproductive season, which coincided with the sampling time (Hung-Chang Liu, pers. obs.).

However, individuals of all four species showed a wide range of total lipid levels in their midgut glands ranging from as low as 3 to $4 \%_{\mathrm{DM}}$ in G. albogilva and P. affine, respectively, to more than $40 \%_{\mathrm{DM}}$ in $P$. affine and about $25 \%_{\mathrm{DM}}$ in G. albogilva. This wide lipid range indicates a high individual variability, which seems to differ from

Table 4 Various dietary indices derived from the midgut gland FAs of four crab species sampled in Taiwan. The dietary indices reflect the consumption of carnivorous diet $\left(I_{C a}\right)$, Chlorophyta $\left(I_{C h}\right)$, Phaeophyta $\left(I_{P}\right)$, Rhodophyta $\left(I_{R}\right)$, and Bacillariophyceae $\left(I_{B}\right)$. All values are means \pm SD ( $n=12$ for each species)

\begin{tabular}{cllll}
\hline Dietary index & Per. aff. & Gra. alb. & Ori. int. & Geo. alb. \\
\hline$I_{C a}$ & $0.18 \pm 0.03$ & $0.25 \pm 0.050$. & $0.47 \pm 0.26$ & $0.51 \pm 0.22$ \\
$I_{C h}$ & $6.01 \pm 1.24$ & $7.57 \pm 1.69$ & $4.56 \pm 1.74$ & $3.17 \pm 1.12$ \\
$I_{P}$ & $1.48 \pm 0.99$ & $0.37 \pm 0.64$ & $0.34 \pm 0.96$ & $0.00 \pm 0.00$ \\
$I_{R}$ & $0.28 \pm 0.07$ & $0.21 \pm 0.09$ & $0.35 \pm 0.21$ & $0.28 \pm 0.15$ \\
$I_{B}$ & $4.36 \pm 2.16$ & $2.64 \pm 0.86$ & $3.11 \pm 1.13$ & $1.50 \pm 1.38$ \\
\hline
\end{tabular}

the more distinct seasonal lipid cycles of polar zooplankton $[24,25]$ or crabs and shrimps from higher latitudes $[16,26]$. Moreover, low lipid levels were not predominantly assigned to specimens, which starved for 12 days after capture, but were also determined in animals from the field. Some starved animals even exhibited quite high lipid contents suggesting good nourishment before capture.

On average, TL values were lower than those of temperate decapod crabs, which frequently reach $50 \%_{\mathrm{DM}}$ $[10,16,27]$. Temperature and illumination are constantly high and support a continuous primary production in both, the marine and the terrestrial realm. This leads to a constant food supply of plant material, such as vascular plants or algae. Due to this year-round food availability, tropical and warm temperate marine and terrestrial crabs do not have to accumulate larger energy reserves as for instance required for their cold temperate counterparts from Europe $[16,26]$, which may explain the generally lower lipd levels. The lipid levels reported here are in line with values of other tropical crabs as, for instance, mud crabs Scylla paramamosain from southern China, which reached hepatopancreas lipid levels of about $24.4 \%_{\text {DM }}$ [28].

Triacylglycerol (TAG) levels were closely correlated with TL levels, as lipids in the midgut glands of decapods are stored predominantly in the form of TAG [26, 29]. TAG as primary storage compound in decapod crustaceans has also been reported for temperate decapod species, namely Carcinus maenas and Hemigrapsus sanguineus [16], and the pink shrimp Pandalus montagui [26]. Correspondingly, the proportion of polar lipids (PL) decreased from low lipid levels towards high lipid levels, as they are rather constant components of total lipids with structural functions, e.g. forming biomembranes.

\section{Dietary preferences: evidence of FA markers}

The high variation in total lipid levels and, thus, in storage TAG allowed detailed analyses of the changes and 
variations of the FA composition with increasing nutritional status. The individuals of all species with low lipid levels clustered in the PCA, whereas species with increasing lipid contents showed specific allocation patterns. The graphical illustration even suggests that the dispersion of species starts from a common origin and spreads radially with increasing storage lipids. The similarity between the lipid-poor crabs indicates that the basic FA composition, necessary to maintain cell membranes and organ functions, appears similar in all four species. The dissimilarity of the well-fed and lipid-rich animals reflects the different feeding habits and food sources of each species. This makes sense, since dietary fatty acids are accumulated in the depot lipids (i.e., TAG) and the higher the lipid level, the stronger the trophic signatures with a higher resolution $[8,15]$. This observation emphasizes the better suitability of the FATM concept for more lipid-rich than for lipid-poor specimens, as shown in many pelagic organisms [8]. It also underlines the need for sufficient sample sizes in lipid and FA studies that represent a wide range of lipid levels to resolve trends and differences in feeding preferences of decapod crabs or other organisms.

All four species show high amounts of arachidonic acid 20:4(n-6), which is, among other polyunsaturated fatty acids (PUFA), considered to be essential and synthesized de novo by plants, e.g., Rhodophyta and Phaeophyta [30]. As marine animals are considered not to be able to synthesize these PUFAs [8], their storage in the midgut glands suggests an at least partially plant-based diet. Thus, the generally high levels of arachidonic acid 20:4(n-6) indicate herbivory, but do not allow to distinguish between terrestrial or marine sources. Overall, the differences in the contributing portions of single FAs still led to separate clusters, or better allocation patterns, of marine and terrestrial species in the PCA.

These differences in FA compositions are also reflected in different dietary indices of the four crab species. However, these indices should not be interpreted independently from each other, as exemplified by the indices for the consumption of algae. The Chlorophyta index is relatively high in the terrestrial G. albogilva, which obviously does not encounter chlorophyte algae. The Chlorophyta index is composed of the FAs vaccenic acid 18:1(n-7) and $\alpha$ linolenic acid 18:3(n-3). The latter FA is also a common component in vascular plants [15] and here it is similarly abundant in all four crab species (Table 4).

The dietary indices of the two terrestrial species are quite similar, although they indicate a higher consumption of diatoms (Bacillariophyceae) by O. intermedium. Living along estuaries and in salt marshes, this species may have access to and ingest diatoms, which is unlikely in the case of G. albogilva. The dietary indices of the two marine species suggest that $P$. affine feeds on Phaeophyceae to a higher degree than $G$. albolineatus. P. affine also seems to ingest more diatoms.

The most striking difference between the two groups of crabs is the strongly differing vascular plant index. This index is almost twice as high in the two terrestrial species compared to the marine species and clearly indicates a higher proportion of a vascular plant diet in the terrestrial species. Thus, this FA trophic marker generally corroborates the sparse knowledge about the herbivorous feeding preferences of these four crab species or close relatives [1, 18, 31-33] (Hung-Chang Liu, pers. obs.).

\section{Distinguishing marine from terrestrial food sources by FA ratios}

16:0/I $I_{V}$ and $\Sigma_{\text {algae } F A} / I_{V}$ were defined to differentiate between marine and terrestrial food sources of the crabs. Both indices show the same trends. The ratios decrease the more a crab species is assumed to follow a terrestrial lifestyle. The major difference between the two indices is the inclusion of the membrane FA 16:0. 16:0/I $\mathrm{I}_{V}$ reflects best the gradually increasing importance of terrestrial food sources in the four crab species, from $P$. affine over G. albolineatus and O. intermedium to G. albogilva. However, $\Sigma_{\text {algae } F A} / I_{V}$ splits the four species more accurately into two groups: $P$. affine and $G$. albolineatus as marine species with significantly higher ratios on the one hand compared to O. intermedium and G. albogilva as terrestrial species on the other hand.

The applicability of such ratios is supported, when applying the indices to other crab species with a betterknown nutritional ecology. The two fully marine brachyurans Hemigrapsus sanguineus and Carcinus maenas showed high values for the $\Sigma_{\text {algae } \mathrm{FA}} / \mathrm{I}_{V}$ ratio of 9.1 and 11.5 , respectively, which clearly reflect their marine diet [16]. In contrast, the FA ratios for $\Sigma_{\text {algae }} \mathrm{FA} / \mathrm{I}_{V}$ of two semi-terrestrial crayfishes, Cherax destructor and Engaeus sericatus of 1.3 and 3.2, respectively, indicate a terrestrial diet [34]. However, both pairs of crabs are not strictly herbivorous, similar to the four crab species from Taiwan investigated here. This may explain the differences in the ratios within each pair of crabs, even if $H$. sanguineus and $C$. maenas are both fully marine and $C$. destructor and E. sericatus can both be regarded as semiterrestrial.

\section{Conclusion}

Application and adaptation of the fatty acid trophic marker concept to studies of the feeding ecology and dietary preferences of four decapod crustaceans from Taiwan provide clear evidence that the trophic niches of these largely unknown crab species can be determined. Hence, dietary indices based on trophic marker fatty 
acids proved to be a suitable tool for identifying foodweb relationships. In addition to the already published indices, we propose two new indices for distinguishing crabs having a vascular plant-dominated diet from crabs with marine diets. This may be especially relevant for feeding studies of species living in habitats that are characterized by both food sources, such as mangrove forests and salt marshes.

\section{Methods}

\section{Origin of samples}

Males of the four crab species Percnon affine (H. Milne Edwards, 1853), Grapsus albolineatus (Latreille in Milbert, 1812), Orisarma intermedium (Schubart \&Ng, 2020), and Geothelphusa albogilva (Shy, Ng \& Yu, 1994), were collected in the southern part of Taiwan in May 2007 (Fig. 1, Table 1). Only specimens in the intermoult stage with hardened carapaces were taken. The two marine species were collected during nighttime and transported in aerated seawater to the laboratories of the Providence University in Shalu. The semi-terrestrial and terrestrial species were collected at day and transported in containers with some freshwater to the Shalu laboratories. Additionally, potential food items were collected: Ulva spp. for the two marine species, the grasses Panicum sp./Paspalum sp. for O. intermedium, and leaf litter of vascular plants for G. albogilva. The collected leaf litter could not be identified to genus or species level. However, the most common plant species around the collection site and, thus, potential terrestrial food sources were Broussonetia papyrifera, Hibiscus taiwanensis, Macaranga tanarius, Diospyros eriantha, and Bischofia javanica.

Eight individuals per species were immediately processed in the laboratory as described below. To increase the number of specimens with a low lipid content, four individuals of each species were starved for 12 days before tissue samples were taken.

The two marine species, $P$. affine and G. albolineatus, were maintained at $25^{\circ} \mathrm{C}$ and a light/dark cycle of $12: 12$ h. P. affine was kept in $40 \mathrm{~L}$ tanks with aerated seawater. G. albolineatus was maintained in tanks $(60 \times 80 \mathrm{~cm})$, where only the bottom of the tank was covered with seawater. The water was exchanged two to three times per day. The two terrestrial species, O. intermedium and G. albogilva, were incubated at $25{ }^{\circ} \mathrm{C}, 80 \%$ humidity, and a light/dark cycle of 12:12 h. Freshwater was provided for drinking. Except for G. albogilva, all individuals were kept separately in sub-compartments in the tanks to avoid aggression and cannibalism.

\section{Tissue dissection}

The crabs were placed on crunched ice to chill and sedate them. After a few minutes, the crabs were immobile.
The fresh mass of each crab was determined and the carapace width was measured. The midgut gland was dissected, the wet mass of the midgut gland was determined, and the tissue was immediately frozen at $-80^{\circ} \mathrm{C}$. The hepatosomatic index (HSI) was calculated as the relationship between the fresh mass of the midgut gland $\left(M_{M G G}\right)$ and the total crab fresh mass $\left(M_{C r a b}\right)$ :

$$
H S I(\%)=100 \frac{M_{M G G}}{M_{C r a b}}
$$

Crab midgut gland samples and plant samples were lyophilized at Shula labs for $48 \mathrm{~h}$ (BioTron, Ecospin 3180C) and transported to the Marine Zoology laboratory at the University of Bremen, Germany, on a desiccant (silica gel) and at ambient temperatures of 20 $25^{\circ} \mathrm{C}$. After arrival, the samples were immediately stored at $-80^{\circ} \mathrm{C}$.

\section{Lipid analyses}

The dry mass of the lyophilized midgut glands was determined gravimetrically. Subsequently, lipids were extracted with dichloromethane: methanol (2:1, per volume) and an aqueous solution of $0.88 \% \mathrm{KCl}[35,36]$. The mass of the extracted lipids $\left(M_{T L}\right)$ was determined gravimetrically and the total lipid $(T L)$ content was calculated as percentage of the dry mass of the midgut gland sample $\left(D M_{M G G}\right)$ :

$$
T L\left(\%_{D M}\right)=100 \frac{M_{T L}}{D M_{M G G}}
$$

Lipid classes were separated and quantified using Thin-Layer Chromatography with an integrated flame ionization detector (MK-5 TLC/FID analyzer, Iatron Laboratories) [37]. Each sample was run in duplicate. Free fatty acid levels were $\leq 1.1 \%_{\mathrm{TL}}$, indicating that no relevant degradation (autolysis) occurred during sample processing.

Fatty acids (FA) were analyzed after [38, 39]. A subsample of the extracted lipids of each midgut gland was converted to fatty acid methyl esters (FAME) by applying methanol containing 3\% concentrated sulfuric acid. The FAME were quantified by gas chromatography (GC). The GC device was equipped with a DB-FFAP column (30 m length, $0.25 \mathrm{~mm}$ diameter), a programmable temperature vaporizer injector, and a flame ionization detector (FID). Helium was used as carrier gas. FA were identified by retention times and by using a fish oil standard (Marinol). Free fatty alcohols and most unidentified components accounted for on average less than $1 \%$ per species, except for an unidentified component with a mean of $5.5 \%$ in O. intermedium. Free fatty alcohols and unidentified components were not further considered in the present study. 
Table $\mathbf{5}$ List of various fatty acid-based trophic marker indices

\begin{tabular}{ll}
\hline Carnivory Index & $I_{C a}=\frac{18: 1(n-9)}{[16: 1(n-7)+16: 4(n-1)+18: 1(n-7)+18: 2(n-6)+18: 3(n-3)+18: 4(n-3)+20: 4(n-6)+20: 5(n-3)]}$ \\
Chlorophyta Index & $I_{C h}=18: 1(n-7)+18: 3(n-3)$ \\
Phaeophyceae Index & $I_{P}=18: 4(n-3)$ \\
Rhodophyta Index & $I_{R}=\frac{20: 5(n-3)}{[16: 0+18: 0+22: 6(n-3)]}$ \\
Bacillariophyceae Index & $I_{B}=16: 1(n-7)+16: 4(n-1)$ \\
Vascular Plant Index & $I_{V}=18: 2(n-6)$ \\
16:0/IV & $16: 0 / I_{V}=\frac{16: 0}{18: 2(n-6)}$ \\
$\Sigma_{\text {algae FA } / I_{V}}$ & $I_{T}=\frac{[16: 1(n-7)+16: 4(n-1)+18: 1(n-7)+18: 3(n-3)+18: 4(n-3)+20: 4(n-6)]}{18: 2(n-6)}$ \\
\hline
\end{tabular}

\section{Fatty acid trophic markers}

The FA dataset was interpreted according to the fatty acid trophic marker concept. The set of dietary indices [16] was adapted and extended to identify food sources of marine and terrestrial origin. In comparison, hexadecatetraenoic acid 16:4(n-3) was removed from the index for carnivorous diet and the Chlorophyta index, because it was not detected in the present samples. Likewise, linoleic acid 18:2(n-6) was omitted from the Chlorophyta index, because it serves as vascular plant index here [8, 15]. Following the species gradient from fully marine to fully terrestrial, the percentage of 16:0 was found to decrease constantly, whereas the opposite was true for the vascular plant index $18: 2(\mathrm{n}-6)\left(=\mathrm{I}_{V}\right.$; see Results). Thus, the potential of a ratio between these two FA as a marine/terrestrial index was tested. Palmitic acid 16:0 is a biomembrane fatty acid [14, 40]. Therefore, its proportion is also dependent on the amount of stored lipid, i.e. the total lipid content. As a non-biomembrane alternative, a ratio between all algae FA $\left(\sum_{\text {algae FA }}\right)$ and 18:2(n-6) was tested as well. All parameters and their equations used in this study are summarized in Table 5. Even though some indices, e.g., algae indices for the terrestrial crabs, are not reasonable per se, we show all results for better comparison. More detailed information on the biomarker function of certain FAs can be found in dedicated review articles [8, 14, 41].

\section{Statistical analyses}

Data sets of HSI and dietary indices were tested for normal distribution with the D'Agostino \& Pearson omnibus test. If they passed normality tests, data were compared with a One-Way ANOVA, followed by the Tukey's post hoc test. If normality tests failed or the number of samples was too small, we applied the Kruskal Wallis test, followed by the Dunn post hoc test. The significance level was $\alpha=0.05$.

A sigmoidal model was applied to illustrate the ordinate course of lipid contents as well as the relation between triacylglycerols (TAG) and the total lipid content:

$$
f(x)=a+\frac{b}{1+e^{\frac{x-m}{s}}}
$$

with $\mathrm{a}=$ minimum of the fit, $\mathrm{b}=$ maximum of the fit, $\mathrm{m}=$ point of inflection, $50 \%$ level of the function, $\mathrm{s}=$ slope at the point of inflection. Statistical analyses and graphical presentation of the data were conducted with the software GraphPad Prism (version 7.05).

A principal component analyses (PCA) was conducted with the entire FA data set of the crabs. FA percentage values of all samples were transformed to proportions (0 to 1$)$ and arcsine-square-root transformed to achieve normality and homogeneity of variances. PCAs were conducted and the corresponding graphs were plotted with the software Primer v7 [42].

\section{Supplementary Information}

The online version contains supplementary material available at https://doi. org/10.1186/s12983-021-00405-0.

Additional file 1: Source information of Fig. 1. Table S1. Morphometric data of crab species. Table S2. Hepatosomatic indices of crab species. Table S3. Eigenvalues of PCA. Table S4. Eigen vectors of PCA. Table S5. Dietary indices complementing Fig. 5. Fig. S1. Relation between total lipids and fatty acid contents.

Additional file 2. Animated gif. Land crabs PCA.gif.

\section{Acknowledgments}

We gratefully acknowledge the logistical, technical, and analytical support of the participating laboratories, namely Petra Wencke.

\section{Authors' contributions}

MS, RS, and WH designed the study. RS and WH supervised the study and the laboratory analysis in Germany. MS carried out the field sampling, maintenance of crabs, tissue sampling, and transport of the samples. $\mathrm{HCL}$ carried out and supervised on-site sampling and provided laboratory facilities in Taiwan. MS performed the lipid and fatty acid analyses. MS, RS, and SJ analyzed the data. MS, RS, SJ, and WH wrote the manuscript. The authors read and approved the final manuscript.

\section{Authors' information}

Meike Stumpp.

Christian Albrechts University, Zoological Institute, Am Botanischen Garten 3-9, 24118 Kiel, Germany. Email: mstumpp@zoology.uni-kiel.de Reinhard Saborowski.

Alfred Wegener Institute, Helmholtz Centre for Polar and Marine Research, Am Handelshafen 12, 27515 Bremerhaven, Germany. Email: Reinhard.

Saborowski@awi.de 
Simon Jungblut.

University of Bremen, BreMarE (Bremen Marine Ecology), Marine Botany, PO Box 330 440, 28334 Bremen, Germany. Email: simon.jungblut@awi.de Hung-Chang Liu.

Land Crab Ecology Research Laboratory, 53 Chenggong 11th St., Jubei City, Hsinchu County 302, Taiwan. Email: labuanium@gmail.com

Wilhelm Hagen.

University of Bremen, BreMarE (Bremen Marine Ecology), Marine Zoology and MARUM Center of Environmental Sciences, PO Box 330 440, 28334 Bremen, Germany. Email: whagen@uni-bremen.de

\section{Funding}

This study received no external funding. Open Access funding enabled and organized by Projekt DEAL.

\section{Availability of data and materials}

The datasets generated during and/or analyzed during the current study will be available in the PANGAEA repository [https://www.pangaea.de].

\section{Declarations}

\section{Ethics approval and consent to participate}

All applicable international, national and institutional guidelines for the care and use of animals were followed. All procedures performed in studies involving animals were in accordance with the ethical standards of the institution at which the studies were conducted.

\section{Consent for publication}

Not applicable.

\section{Competing interests}

The authors declare that they have no competing interests.

\section{Author details}

${ }^{1}$ University of Bremen, BreMarE (Bremen Marine Ecology), Marine Zoology, PO Box 330 440, 28334 Bremen, Germany. ${ }^{2}$ Christian-Albrechts-University, Zoological Institute, Am Botanischen Garten 3-9, 24118 Kiel, Germany. ${ }^{3}$ Alfred Wegener Institute, Helmholtz Centre for Polar and Marine Research, Am Handelshafen 12, 27515 Bremerhaven, Germany. ${ }^{4}$ Present address: University of Bremen, BreMarE (Bremen Marine Ecology), Marine Botany, PO Box 330 440, 28334 Bremen, Germany. ${ }^{5}$ Land Crab Ecology Research Laboratory, 53 Chenggong 11th St., Jubei City, Hsinchu County 302, Taiwan. ${ }^{6}$ University of Bremen, MARUM Center of Environmental Sciences, PO Box 330 440, 28334 Bremen, Germany.

\section{Received: 31 December 2020 Accepted: 28 March 2021}

\section{Published online: 19 May 2021}

\section{References}

1. Puccio V, Relini M, Azzurro E, Orsi RL. Feeding habits of Percnon gibbesi $(\mathrm{H}$. Milne Edwards, 1853) in the Sicily Strait. Hydrobiologia. 2006. https://doi. org/10.1007/s10750-005-1310-2

2. Greenaway P, Raghavem S. Digestive strategies in two species of leaf eating land crabs (Brachyura: Gecacinidae) in a rain forest. Physiol Zool. 1998;71(1): 36-44. https://doi.org/10.1086/515882.

3. Linton SM, Greenaway P. A review of feeding and nutrition of herbivorous land crabs: adaptations to low quality plant diets. J Comp Physiol B. 2007; 177(3):269-86. https://doi.org/10.1007/s00360-006-0138-z.

4. Wolcott DL, O'Connor NJ. Herbivory in crabs: adaptations and ecological considerations. Am Zool. 1992;32(3):370-81. https://doi.org/10.1093/ $\mathrm{icb} / 32.3 .370$

5. Greenaway $P$, Linton SM. Dietary assimilation and food retention time in the herbivorous terrestrial crab Gecarcoidea natalis. Physiol Zool. 1995;68(6): 1006-28. https://doi.org/10.1086/physzool.68.6.30163791.

6. Kennish $\mathrm{R}$, Williams GA. Feeding preferences of the herbivorous crab Grapsus albolineatus: the differential influence of algal nutrient content and morphology. Mar Ecol Prog Ser. 1997;147:87-95. https://doi.org/10.3354/ meps147087.

7. Wilde JE, Linton SM, Greenaway P. Dietary assimilation and the digestive strategy of the omnivorous anomuran land crab Birgus latro (Coenobitidae). J Comp Physiol B. 2004;174(4):299-308. https://doi.org/10.1007/s00360-004-0415-7.
8. Dalsgaard J, St John M, Kattner G, Müller-Navarra D, Hagen W. Fatty acid tropic markers in the pelagic marine environment. Adv Mar Biol. 2003. https://doi.org/10.1016/S0065-2881(03)46005-7.

9. Kyomo J. Analysis of the relationship between gonads and hepatopancreas in males and females of the crab Sesarma intermedia, with reference to resource use and reproduction. Mar Biol. 1988;97(1):87-93. https://doi.org/1 $0.1007 / B F 00391248$

10. Griffen BD, Vogel M, Goulding L, Hartman R. Energetic effects of diet choice by invasive Asian shore crabs: implications for persistence when prey is scarce. Mar Ecol Prog Ser. 2015;522:181-92. https://doi.org/10.3354/meps111 60.

11. Jimenez AG, Kinsey ST. Energetics and metabolic regulation. In: Chang E, Thiel M, editors. The natural history of the Crustacea, Vol 4: physiology. Oxford: Oxford University Press; 2015. p. 391-419.

12. Graeve M, Dauby P, Scailteur Y. Combined lipid, fatty acid and digestive tract content analyses: a penetrating approach to estimate feeding modes of Antarctic amphipods. Polar Biol. 2001;24(11):853-62. https://doi.org/10.1 007/s003000100295

13. Latyshev NA, Khardin AS, Kasyanov SP, Ivanova MB. A study on the feeding ecology of chitons using analysis of gut contents and fatty acid markers. J Molluscan Stud. 2004:70(3):225-30. https://doi.org/10.1093/mollus/70.3.225.

14. Lee RF, Hagen W, Kattner G. Lipid storage in marine zooplankton. Mar Ecol Prog Ser. 2006;307:273-306. https://doi.org/10.3354/meps307273.

15. Kelly JR, Scheibling RE. Fatty acids as dietary tracers in benthic food webs. Mar Ecol Prog Ser. 2012;446:1-22. https://doi.org/10.3354/meps09559.

16. Jungblut S, McCarthy ML, Boos K, Saborowski R, Hagen W. Seasonal lipid storage and dietary preferences of native European versus invasive Asian shore crabs. Mar Ecol Prog Ser. 2018;602:169-81. https://doi.org/10.3354/ meps12712.

17. Kennish R. Seasonal patterns of food availability: influences on the reproductive output and body condition of the herbivorous crab Grapsus albolineatus. Oecologia. 1997;109(2):209-18. https://doi.org/10.1007/s004420050075.

18. Nayar TS, Praveen VP, Suresh S. Species preferences of the crab Sesarmops intermedius to seedling predation in mangrove ecosystem of Kerala, India. In: Dahdouh-Guebas F, Satyanarayana B, editors. Proceeding of the international conference 'Meeting on mangrove ecology, functioning and management, vol. 57. Galle, Sri Lanka: 2-6 July 2012 VLIZ Special Publication; 2012. p. 125.

19. Chu T, Sheng Q, Wang S, Huang M, Wu J. Population dynamics and secondary production of crabs in a Chinese salt marsh. Crustaceana. 2013; 86(3):278-300. https://doi.org/10.1163/15685403-00003167.

20. Shih H-T, Ng PKL, Chang H-W. Systematics of the genus Geothelphusa (Crustacea, Decapoda, Brachyura, Potamidae) from southern Taiwan: a molecular appraisal. Zool Stud. 2004;43:561-70.

21. Ng PKL, Wang C-H, Ho P-H, Shih H-T. An annotated checklist of brachyuran crabs from Taiwan (Crustacea: Decapoda): National Taiwan Museum Special Publication Series, No. 11; 2001

22. Gonzales-Baro M d R, Pollero RJ. Lipid characterization and distribution among tissues of the freshwater crustacean Macrobrachium borellii during an annual cycle. Comp Biochem Physiol B. 1988. https://doi.org/10.1016/03 05-0491(88)90197-6.

23. Mourente G, Medina A, Gonzáles S, Rodríguez A. Changes in lipid class and fatty acid contents in the ovary and midgut gland of the female fiddler crab Uca tangeri (Decapoda, Ocypodoidea) during maturation. Mar Biol. 1994;121(1):187-97. https://doi.org/10.1007/BF00349488.

24. Hagen W, Van Vleet ES, Kattner G. Seasonal lipid storage as overwintering strategy of Antarctic krill. Mar Ecol Prog Ser. 1996;134:85-9. https://doi.org/1 0.3354/meps134085

25. Hagen W, Auel H. Seasonal adaptations and the role of lipids in oceanic zooplankton. Zoology. 2001;104(3-4):313-26. https://doi.org/10.1078/0944-2 006-00037.

26. Martínez-Alarcón D, Saborowski R, Melis E, Hagen W. Seasonal lipid dynamics of the shrimps Crangon crangon and Pandalus montagui in the German bight (North Sea). Mar Ecol Prog Ser. 2019;625:41-52. https://doi. org/10.3354/meps13046

27. Wen $X$, Chen L, Ku Y, Zhou K. Effect of feeding and lack of food on the growth, gross biochemical and fatty acid composition of juvenile crab, Eriocheir sinensis. Aquaculture. 2006;252(2-4):598-607. https://doi.org/10.101 6/j.aquaculture.2005.07.027

28. Zhao J, Wen X, Li S, Zhu D, Li Y. Effects of dietary lipid levels on growth, feed utilization, body composition and antioxidants of juvenile mud crab 
Scylla paramamosain (Estampador). Aquaculture. 2015;435:200-6. https://doi. org/10.1016/j.aquaculture.2014.09.018.

29. O'Connor JD, Gilbert LI. Aspects of lipid metabolism in crustaceans. Am Zool. 1968;8(3):529-39. https://doi.org/10.1093/icb/8.3.529.

30. Li X, Fan X, Han L, Lou Q. Fatty acids of some algae from the Bohai Sea. Phytochemistry. 2002;59(2):157-61. https://doi.org/10.1016/50031-9422(01 )00437-X.

31. Kennish R, Williams GA, Lee SY. Algal seasonality on an exposed rocky shore in Hong Kong and the dietary implications for the herbivorous crab Grapsus albolineatus. Mar Biol. 1996;125(1):55-64. https://doi.org/10.1007/BF003 50760.

32. Kennish R. Diet composition influences the fitness of the herbivorous crab Grapsus albolineatus. Oecologia. 1996;105(1):22-9. https://doi.org/10.1007/ BF00328787.

33. Pipitone C, Badalamenti F, Sparrow A. Contribution to the knowledge of Percnon gibbesi (Decapoda, Grapsidae), an exotic species spreading rapidly in Sicilian waters. Crustaceana. 2001;74(10):1009-17. https://doi.org/10.11 63/15685400152691061.

34. Linton SM, Allardyce BJ, Hagen W, Wencke P, Saborowski R. Food utilization and digestive ability of aquatic and semi-terrestrial crayfishes, Cherax destructor and Engaeus sericatus (Astacidae, Parastacidae). J Comp Physiol B. 2009. https://doi.org/10.1007/s00360-008-0332-2.

35. Folch J, Lees M, Sloane-Stanley GH. A simple method for the isolation and purification of total lipids from animal tissues. J Biol Chem. 1957;226(1):497509. https://doi.org/10.1016/50021-9258(18)64849-5.

36. Hagen W. Lipids. In: Harris R, Wiebe R, Lenz J, Skjøldal H-R, Huntley M, editors. ICES zooplankton methodology manual. 1st ed. San Diego: Academic Press; 2000. p. 113-9.

37. Fraser AJ, Tocher DR, Sargent JR. Thin-layer chromatography-flame ionization detection and the quantitation of marine neutral lipids and phospholipids. J Exp Mar Biol Ecol. 1985;88(1):91-9. https://doi.org/10.1016/ 0022-0981(85)90204-7.

38. Kattner G, Fricke HSG. Simple gas-liquid chromatographic method for the simultaneous determination of fatty acids and alcohols in wax esters of marine organisms. J Chromatogr. 1986;361:263-8. https://doi.org/10.1016/ 50021-9673(01)86914-4.

39. Peters J, Renz J, van Beusekom J, Boersma M, Hagen W. Trophodynamics and seasonal cycle of the copepod Pseudocalanus acuspes in the Central Baltic Sea (Bornholm Basin): evidence from lipid composition. Mar Biol. 2006;149(6):1417-29. https://doi.org/10.1007/s00227-006-0290-8.

40. Boissonnot L, Niehoff B, Hagen W, Søreide J, Graeve M. Lipid turnover reflects life-cycle strategies of small-sized Arctic copepods. J Plankton Res. 2016. https://doi.org/10.1093/plankt/fbw076.

41. Parrish C. Lipids in marine ecosystems. Int Sch Res Notices. 2013;2013:1-16. https://doi.org/10.5402/2013/604045.

42. Clarke K, Warwick R. Changes in marine communities: an approach to statistical analysis and interpretation. 2nd ed. Plymouth: Primer-E; 1994.

\section{Publisher's Note}

Springer Nature remains neutral with regard to jurisdictional claims in published maps and institutional affiliations.

Ready to submit your research? Choose BMC and benefit from:

- fast, convenient online submission

- thorough peer review by experienced researchers in your field

- rapid publication on acceptance

- support for research data, including large and complex data types

- gold Open Access which fosters wider collaboration and increased citations

- maximum visibility for your research: over $100 \mathrm{M}$ website views per year

At BMC, research is always in progress.

Learn more biomedcentral.com/submissions 